\title{
HUKUM EKONOMI SEBAGAI PANGLIMA PEMBANGUNAN
}

\author{
Purwanto*
}

\begin{abstract}
The law is supreme that must be obeyed by every citizen and must be upheld by the State in the context of national, state and community life. The constitutional foundation provides an understanding that the administration of the Indonesian State is based on the concept of law. The role of law in the reform era in all fields of science is concrete evidence, essentially the life of the community requires a set of legal rules that can always maintain order and furthermore provide legal certainty, usefulness and justice. The problem to be discussed in this paper the author wants to know "How the Role of Economic Law as the Commander in Chief of Development" Economic development must be done through a strong legal foundation. Economics is the backbone of people's welfare, and science is the pillar of national progress, but the law is the institution that ultimately determines how the people's welfare can be enjoyed equally, and how social justice can be realized in people's lives, and how scientific progress and technology can bring progress to the people.
\end{abstract}

Keywords: Economic Law, science and technology, Commander in Development

\section{PENDAHULUAN}

Hukum adalah supreme yang harus ditaati oleh setiap warga Negara dan harus ditegakkan oleh Negara dalam rangka kehidupan berbangsa, bernegara dan bermasyarakat. Landasan konstitusional tersebut memberikan pemahaman bahwa penyelenggaraan Negara Indonesia adalah di dasarkan pada konsep hukum. Peran hukum dalam era reformasi di segala bidang ilmu merupakan bukti nyata, secara hakiki kehidupan masyarakat memerlukan seperangkat aturan hukum yang selalu dapat menjaga ketertiban dan lebih jauh lagi memberikan kepastian hukum, kemanfaat

* Purwanto adalah Pengajar di Fakultas Hukum Universitas 17 Agustus 1945 Semarang dapat dihubungi melalui email : dosenpurwanto @gmail.com an dan keadilan.

Prof.Dr. W. Verwey, salah seorang ahli hukum ekonomi Belanda, mengatakan bahwa pengaturan hubungan ekonomi internasional setelah PD II banyak mengandalkan prinsip-prinsip hukum ekonomi internasional klasik seperti prinsip kebebasan (free trade), non diskriminasi (equality) dan timbal balik (reciprocity). Prinsip-prinsip ini banyak diterapkan pada masa colonial untuk kepentingan negaranegara industri maju. Globalisasi ekonomi dan perdagangan bebas dunia selain dapat menyingkirkan industri kecil di negaranegara sedang berkembang juga menambah ketergantungan ekonomi negara- negara sedang berkembang pada negara-negara maju.

Hukum ekonomi di Belanda yaitu Wirtschafrecht dan di Prancis droit 
economique yang mula-mula muncul sebagai akibat penerapan konsep Negara hukum kesejahteraan (the Welfarestate). Konsep negara kesejahteraan tersebut mengharuskan pemerintah untuk turut campur tangan dalam kehidupan ekonomi demi kesejahteraan seluruh rakyat. Campur tangan pemerintah dalam kehidupan ekonomi bersifat membatasi berlakunya asas kebebasan berkontrakdan berusaha dalam sistem ekonomi liberal (sistem ekonomi klasik).

Menurut Sunaryati Hartono bahwa: "Pelaksanaan pembangunan Indonesia melalui rencana Pembangunan (Repelita di masa ORBA), telah menimbulkan kaidahkaidah hukum baru yang menyimpang dari kaidah-kaidah hukum publik dan hukum privat. Kaidah-kaidah hukum baru tersebut harus ditampung dalam cabang hukum.

Implementasi kedua konsep (ekonomi dan Hukum) yang dijadikan stand point dalam memandang tujuan dalam kehidupan berbangsa dan bernegara inilah yang seringkali mendikotomi berbagai program perencanaan dan pelaksanaan arah pembangunan suatu bangsa, yang pada akhirnya akan menimbulkan conflic of interest.

Latar belakang mengawali uraian pembahasan mengenai peran hukum ekonomi dalam panglima pembangunan, tanpa bermaksud menyamakan persepsi secara mutlak, tetapi setidaknya memberi kan pemahaman dari sudut pandang yang berbeda yang justru diperlukan dalam sistem pembangunan ekonomi itu sendiri.

\section{PERUMUSAN MASALAH}

Permasalahan yang akan dibahas dalam tulisan ini adalah tentang
"Bagaimana Peran Hukum Ekonomi Sebagai Panglima Terhadap Pembangunan"

\section{PEMBAHASAN}

\section{Konsep Hukum Pembangunan Ekonomi}

J.D Ny Hart mengemukakan adanya enam konsep hukum yang mempunyai pengaruh bagi pengembangan kehidupan ekonomi. ${ }^{1}$ yaitu sebagai berikut:

Pertama, prediktabilitas; hukum harus mempunyai kemampuan untuk memberikan gambaran pasti di masa depan mengenai keadaan atau hubunganhubungan yang dilakukan pada masa sekarang. Kedua, faktor penyeimbangan; system hukum harus dapat menjadi kekuatan yang memberikan keseimbangan di antara nilainilai yang bertentangan di dalam masyarakat. Sistem hukum memberikan "kesadaran akan keseimbang an" dalam usaha-usaha negara melakukan pembangunan ekonomi. Ketiga, definisi dan kejernihan tentang status; di samping fungsi hukum yang memberikan prediktabilitas dapat ditambahkan bahwa fungsi hukum juga memberikan ketegasan mengenai status orang-orang dan barangbarang di masyarakat. Keempat, akomodasi; perubahan yang cepat sekali pada hakikatnya akan menyebabkan hilangnya keseimbangan yang lama, baik dalam hubungan antara individu maupun kelompok di dalam masyarakat. Keadaan ini dengan sendirinya menghendaki dipulihkannya keseimbangan tersebut melalui satu dan lain jalan. Di sini sistem

1 Sulistiyo \& Rustamaji, 2009: 20-21 
hukum yang mengatur hubungan antara individu baik secara material maupun formal memberi kesempatan kepada keseimbangan yang terganggu itu untuk menyesuaikan diri kepada lingkungan yang baru sebagai akibat perubahan tersebut. Pemulihan kembali ini dimungkinkan oleh karena di dalam kegoncangan ini system hukum memberikan pegangan kepastian melalui perumusan-perumusan yang jelas dan definitif, membuka kesempatan bagi dipulihkannya keadilan melalui prosedur yang tertib dan sebagainya. Kelima, kemampuan prosedural; pembinaan di bidang hukum acara memungkinkan hukum material itu dapat merealisasikan dirinya dengan baik, ke dalam pengertian hukum acara ini termasuk tidak hanya ketentuan-ketentuan hukum perundangundangan melainkan juga semua prosedur penyelesaian yang disetujui oleh para pihak yang bersengketa, misalnya bentuk-bentuk: arbitrasi, konsiliasi dan sebagainya, semua lembaga tersebut hendaknya dapat bekerja dengan efisien apabila diharapkan. Bahwa kehidupan ekonomi itu ingin mencapai tingkatannya yang maksimum. Keenam, kodifikasi daripada tujuan-tujuan; perundang-undangan dapat dilihat sebagai suatu kodifikasi tujuan serta maksud sebagaimana dikehendaki oleh negara. Di bidang ekonomi, misalnya, kita akan dapat menjumpai tujuan-tujuan itu seperti dirumuskan di dalam beberapa perundangundangan yang secara langsung atau tidak langsung mempunyai pengaruh terhadap bidang perekonomian. Bagi seorang ahli ekonomi maka yang menjadi sumber hukum adalah kebutuhan-kebutuhan ekonomi dalam masyarakat. Karena dengan adanya kebutuhan-kebutuhan ekonomi akan menimbulkan persaingan antara warga masyarakat itu sendiri yang akhirnya persaingan itu apabila tidak diatur dapat menimbulkan kekacauan.

Sehubungan dengan itu maka dibentuklah hukum yang tugasnya untuk mengatur masalah-masalah tersebut. Hukum di samping untuk memberikan kepastian dalam berbisnis, juga untuk mencapai rasa keadilan bagi para pelaku tindak ekonomi di mana pun mereka berada. Hukum tidak dapat berkembang tanpa dukungan ekonomi yang tumbuh. Tetapi, perekonomian tidak akan tumbuh dan berkembang jika hukum tidak mampu menjamin keadilan yang pasti dan kepastian yang adil. Dengan demikian hukum juga dapat difungsikan dan berfungsi sebagai sarana penggerak dan pengarah guna mencapai tujuan-tujuan suatu masyarakat di bidang perekonomian.

\section{P e r a a n H u um D a l a m Pembangunan Ekonomi}

Peranan Hukum Ekonomi sebagai Panglima Pembangunan Sir William Blackstone seorang professor pertama hukum di oxford University, pengacara dan hakim di Inggris pernah menulis bahwa : "For as God, when He created matter, and endued it with a principle of mobility, established certain rules for the perpetual direction of that motion; so, when he created man, and endued him with free will to conduct himself in all parts of life, He laid down certain immutable laws of human nature, whereby that free will is in some degree regulated and restrained, and gave him also the faculty of reason to discover the purport of those laws. (ketika Dia (Tuhan) menciptakan manusia, dan memberikan karunia kebebasan kepadanya 
untuk menentukan apapun dalam hidupnya. Dia menurunkan sejumlah hukum abadi yang sifatnya manusiawi yang melaluinya kebebasan manusia diatur dan dibatasi, serta memberikan kepadanya kekuatan akal untuk menemukan maksud tersembunyi dari hukum-hukum tersebut)." Makna yang dapat dipahami dari komentar Sir William Blackstone tersebut adalah bahwa hukum pada hakekatnya merupakan kodrat yang menyertai kebebasan yang dianugrahkan oleh Tuhan kepada manusia. Oleh karena itu, Hukum Tuhan tiada bandingannya, manusia hanyalah menafsirkan dan seharusnya menyesuaikan tingkah lakunya terhadap hukum itu, tetapi tidak membuat hukum sendiri yang didasarkan pada kehendak bebasnya yang justru bertentangan dengan hukum Tuhan.

Pembangunan ekonomi menurut Baldwin diartikan sebagai suatu proses yang menyebabkan pendapatan percapita penduduk suatu masyarakat meningkat dalam jangka panjang. Dari definisi tersebut terdapat tiga unsur yaitu : (1) Pembangunan ekonomi sebagai suatu proses berarti perubahan yang terus menerus yang di dalamnya telah mengandung unsur-unsur kekuatan sendiri untuk investasi baru; (2) usaha meningkatkan pendapatan per-kapita; dan (3) Kenaikan pendapatan perkapita harus berlangsung dalam jangka panjang.

\section{Peran Pemerintah dalam bidang Ekonomi}

Eksistensi hukum secara langsung dalam bidang ekonomi yang direfleksikan oleh peran negara tersebut, secara factual dapat dilihat pada peran Hukum administrasi Negara yang sangat ber pengaruh dalam kehidupan ekonomi karena hukum administrasi negara adalah bagian dari peraturan perundang-undangan yang berlaku langsung menyentuh kegiatan perekonomian disuatu negara.

Salah satu kebijakan pemerintah dalam kegiatan ekonomi negara misalnya kebijakan moneter dan kebijakan fiskal. Kebijakan moneter adalah kebijakan yang dilakukan otoritas meneter yang mem pengaruhi prekonomian melalui jumlah uang beredar. Yang dipengaruhi adalah stabilitas kurs dan inflasi. Oleh karena itu negara dalam hal ini pemerintah melalui Bank Indonesia (BI) mengeluarkan kebijakan menaikkan harga barang atau menaikkan suku bunga agar animo masyarakat menurun dan daya tabung menjadi tinggi. Demikian contoh pentingnya campur tangan hukum yang direfleksikan sebagai pemerintah atau negara.

Oleh karena itu, keterlibatan pemerintah harus terukur artinya pemerintah memperhitungkan sampai sejauh mana campur tangan pemerintah dalam bidang ekonomi dengan tiga peranan yaitu : (1) sebagai regulator; (2) sebagai Penyedia; dan (3) sebagai pengusaha. Sedangkan fungsi yang paling penting dari hukum adalah memberikan kepastian tentang tindakan relasi dalam melakukan hubungan ekonomi. Tugas utama dari pemerintah adalah menjalankan hukum. dan fungsi utama dari hukum adalah social progress and better standards of life. Pembangunan hukum di Indonesia dapat dikatakan sangat lambat jika dibandingkan dengan pembangunan bidang ekonomi. Akibat dari itu pembangunan ekonomi yang dicapai Indonesia tidak mendapat landasan hukum yang kuat. Khususnyaa 
pada masa pemerintahan orde baru, pembangunan hukum sering disimpangi demi mengejar pertumbuhan ekonomi yang pesat, sehingga menimbulkan berbagai ketimpangan ekonomi seperti kesenjanga kesejahteraan dalam masyarakat, kolusi antara pengusaha dan pejabat, ekonomi biaya tinggi, korupsi dan sebagainya.

Bagaimanapun pembangunan ekonomi haruslah dilakukan melalui landasan hukum yang kuat. Ismail Saleh mengatakan bahwa memang benar bahwa ekonomi merupakan tulang punggun kesejahteraan rakyat, dan memang benar bahwa ilmu pengetahuan adalah tiang-tiang penopang kemajuan bangsa, namun tidak dapat disangkal bahwa hukum merupakan pranata yang pada akhirnya menentukan bagaimana kesejahteraan rakyat tersebut dapat dinikmati secara merata, bagaimana keadilan social dapat diwujudkan dalam kehidupan masyarakat, dan bagaimana kemajuan ilmu pengetahuan dan teknologi dapat membawa kemajuan bagi rakyat banyak.

\section{Hubungan Antara Hukum Dengan Ekonomi.}

Dalam memahami aspek-aspek hukum dalam ekonomi dihadapkan pada dua disiplin ilmu yang berbeda secara bersamaan, yaitu ilmu hukum dan ilmu ekonomi. Ilmu hukum bersifat normatif, idealnya yang merupakan kristalisasi dari sistem nilai, budaya, idiologi, refleksi kebiasaan, serta keputusan otoritas publik. Sementara ilmu ekonomi dapat dikatakan sebagai suatu ilmu yang mempelajari bagaimana dengan alat pemuas kebutuhan yang terbatas manusia dapat memenuhi kebutuhan yang tidak terbatas. Hukum dan ekonomi digambarkan sedemikian erat hubungannya, terutama yang menyangkut bidang ekonomi perusahaan dan ekonomi makro yang ruang lingkupnya mencakup interaksi bisnis diantara para pelaku usaha. Interaksi itu sangat memerlukan aturan hukum yang harus diikuti oleh semua pihak. Dalam konteks apa yang disebut di atas, yang menyusun aturan hukum adalah domein sarjana hukum. Sedangkan memberikan uraian mengenai mekanisme dari kekuatan-kekuatan ekonomi yang bekerja secara alamiah menjadi domein dari para ahli ekonomi. Bila disederhana kan bahwa hukum akan memberi tuntunan, pegangan, serta menciptakan kaedahkaedah hukum bagi kegiatan ekonomi. Hukum dapat dijadikan sebagai alat untuk mencapai tujuan-tujuan ekonomi yang dikehendaki atau yang dicita-citakan.

\section{Fungsi Huku m D a l a m Pembangunan Ekonomi}

Dalam menganalisis fungsi hukum dalam pembangunan perekenomian, maka penting untuk dipahami fungsi hukum dalam masyarakat. Setelah itu, baru dikaitkan dengan fungsi hukum dalam pembangunan ekonomi sebagaimana yang dimaksud dalam kajian tulisan ini. Menurut Satjipto Rahardjo, hukum berfungsi sebagai perlindungan bagi kepentingan manusia, dan karenanya hukum harus dilaksanakan. Selanjutnya Ronny Hanitidjo dengan menyisir pendapat Talcott Parsons, fungsi utama hukum Ialah melakukan integrasi, yaitu mengurangi konflik-konflik dan melancarkan proses interaksi pergaulan sosial. Fungsi internal hukum itu sendiri sudah sangat berpengaruh dalam kehidupan manusia, utamanya dalam kehidupan 
ekonomi. Thomas Aquinas menegaskan dalam konteks ini, bahwa fungsi hukum mengusahakan kesejahteraan seluruh umat manusia. Fungsi disini adalah sebagai kerangka yang berwujud peraturan yang membimbing, memberikan pedoman sanksi dan alat untuk mereknya kehidupan sosial. Obyeknya adalah segala segi kehidupan manusia dalam kehidupan ekonominya.

Dengan demikian, tugas hukum dibidang ekonomi yang terutama adalah untuk dapat senantiasa menjaga dan menciptakan kaedah-kaedah pengaman agar pelaksanaan pembangunan ekonomi tidak akan mengorbankan hak dan kepentingan pihak yang lemah. Hanya dengan cara seperti inilah hukum akan tetap mempunyai peranan yang strategis dalam pembangunan ekonomi. Peranan hukum dalam pembangunan ekonomi begitu penting, bukan hanya dalam menyelesaikan masalah yang timbul, tetapi yang lebih penting lagi adalah dalam meletakkan dasar-dasar dari pembangunan itu sendiri.

\section{Peran Penegak Hukum dalam Pembangunan ekonomi.}

Pembangunan di bidang hukum dalam era reformasi adalah upaya untuk mewujudkan supremasi hukum dengan melakukan berbagai perubahan baik substansi hukum, struktur hukum maupun kultur hukum. Seiring dengan menguatnya pernghormatan dan penghargaan terhadap Hak Asasi Manusia, kebebasan ber pendapat di depan umum, maka masyarakat yang semakin kritis dan konstruktif melalui berbagai unjuk rasa menyampaikan aspirasinya dalam memberikan control kepada pemerintah pada umumnya dan aparat penegak hukum dalam melaksana kan tugas-tugasnya menegakkan supremasi hukum.

Di samping masalah-masalah dalam negeri tersebut, ekonomi Indonesia juga harus menghadapi berbagai tantangan yang timbul dari proses liberalisasi dan globalisasi ekonomi. misalnya kemungkin an timbulnya resesi dan persaingan yang semakin tajam. Dalam era liberalisasi dan globalisasi saat ini daya saing ekonomi menjadi unsur penentu keberhasilan. Khusus di bidang perdagangan barang dan jasa, produksi dalam negeri harus bersaing ketat dengan produksi barang dan jasa buatan luar negeri, yang tidak hanya bersaing di pasar internasional tetapi di pasar domestik. Kebijakan pemerintah disektor industri dan perdagangan juga dibatasi oleh ketentuan-kentuan inter nasional, baik secara multilateral seperti WTO maupun regional seperti AFTAASEAN.

Indonesia sebagai anggota WTO dan AFTA berkewajiban untuk mematuhi dan mendukung ketentuan-ketentuan inter nasional yang telah disepakati bersama. Oleh karena itu perlindungan industri dalam negeri melalui hambatan perdagang an non tariff dan pemberian subsidi sudah harus dihindari.

Dalam menghadapi revolusi teknologi informasi, seperti masalah ecommerce, IT, cyber crime, online marketing, distance selling, setifikat digital, korupsi, money Loundring, terorisme dan berlakunya AFTA, diperlu kan kesiapan regulasi yang relevan dengan kebutuhan perkembangan zaman seperti mengenai arbitrase dan alternatif penyelesaian sengketa, Perseroan terbatas, perusahaan Multinasional, AFTA, anti 
dumping, antitrust, persaingan tidak sehat, perlindungan konsumen, aspek hukum kelautan Indonesia, hukum udara dan ruang angkasa, aspek hukum komersialisasi di masa mendatang, perlindungan HAKI, information technology and communi cation, e-commerce, cyber law ratifikasi ketentua-ketentuan international tentang perdagangan dan ekonomi.

Dalam konstruksi demikian, maka untuk melahirkan suatu lembaga kepolisian yang bersih, berwibawa, dan adil maka harus didukung oleh kondisi perkembangan sosial budaya kenegaraan dan ke masyarakatan yang menjunjung tinggi nilai-nilai demokrasi Pancasila. Peran Polri dalam mengemban tugas dan tanggung jawabnya ikut membangun kultur hukum masyarakat, meskipun tidak mudah, mengingat stigma public trus dari pengalam masa lalu. Selain itu, Polri hanyalah salah satu elemen dari beberapa unsur dalam sistem penegakan hukum, khususnya dalam criminal justice system. Dengan demikian, keberhasilan dalam upaya penegakan hukum harus didukung oleh efektivitas peran masing-masing elemen dalam system hukum tersebut.

Dengan demikian perubahan paradigma kepolisian sebagai institusi penegak hukum, pelindung dan pembimbing masyarakat di samping tergantung pada produk hukum yang menjadi dasar hukumnya yaitu UU No. 2 Tahun 2002, juga bergantung kepada proses demokratisasi, penegakan keadilan danHAM di tingkat negara dan masyarakat.

Penegakan hukum bukanlah penghambat pembangunan ekonomi, tetapi justru menjadi motor penggerak yang akan mengarahkan proses pembangunan ekonomi yang adil dan beradab. Penegakan hukum, akan memastikan terwujudnya keadilan ekonomi, persaingan sehat, dan pemerataan pembangunan di segala bidang. Terkait dengan korupsi dalam BUMN/ BUMD, maka sangat diperlukan campur tangan hukum untuk memastikan pengelola an keuangan negara yang dipisahkan tesebut, dikelola secara profesional, serta dapat memberikan keuntungan bagi sebesar-besarnya kesejahteraan rakyat.

Dengan menggunakan sample data sebanyak 2.300 responden berdasarkan National Survey of Corruption di Indonesia tahun 2001, yang dilakukan oleh Partnership for Governance Reform, Khouw menunjukkan bahwa $65 \%$ dari perusahaan yang menjadi responden menyatakan bahwa koneksi adalah hal yang amat penting untuk memenangi kontrak pembelian pemerintah (government procurement). Bahkan 32 persen menyata kan bahwa suap sebagai faktor yang penting dalam pemenangan tender. Artinya memang ada kecenderungan bahwa dunia usaha tertarik untuk menjadi pemasok suap.

Kondisi sosio-kultural masyarakat terutama tingkat kemiskinan, pendidikan yang rendah, dan krisis moral yang melanda bangsa ini, menjadi salah satu faktor rentannya terjadi praktek suap-menyuap dalam kehidupan sehari-hari. Karena itu, diperlukan suatu proses perubahan perilaku, sikap dan cara pandang masyarakat untuk dijadikan pondasi yang kokoh dalam rangka membangun lembaga masyarakat yang mandiri, berdaya guna, agar mampu bertindak sesuai dengan harkat dan martabat manusia yang luhur dengan menerapkan nilai-nilai luhur dalam kehidupan bermasyarakat berbangsa dan bernegara. 
Demikian juga, pemahaman terhadap perspektif penegakan hukum sangat diperlukan untuk mendukung pem berantasan tindak pidana korupsi yang telah menggrogoti sistem prekonomian Negara ini, karena pemahaman yang keliru terhadap upaya penegakan hukum, justru akan menghambat upaya pemberantasan korupsi itu sendiri yang justru tidak hanya merugikan keuangan dan perekonomian Negara, tetapi telah merusak sendi-sendi sosial, budaya, politik dan ideologi berbangsa dan bernegara.

\section{Sistem Ekonomi yang Berlaku di Indonesia}

Sistem Ekonomi Komando, Sistem Ekonomi Pasar, dan Sistem Ekonomi Campuran adalah tiga sistem ekonomi yang secara umum dikenal di seluruh dunia. Bagaimana dengan sistem ekonomi yang berlaku di Indonesia? Indonesia tidak menganut Sistem Ekonomi Komando, Sistem Ekonomi Pasar, maupun Sistem Ekonomi Campuran. Sistem ekonomi yang diterapkan di Indonesia adalah Sistem Ekonomi Pancasila, yang di dalamnya terkandung demokrasi ekonomi maka dikenal juga dengan Sistem Demokrasi Ekonomi. Demokrasi Ekonomi berarti bahwa kegiatan ekonomi dilakukan dari, oleh, dan untuk rakyat di bawah pengawasan pemerintah hasil pemilihan rakyat.

Dalam pembangunan ekonomi masyarakat berperan aktif, sementara pemerintah berkewajiban memberikan arahan dan bimbingan serta menciptakan iklim yang sehat guna meningkatkan kesejahteraan masyarakat. Salah satu ciri positif demokrasi ekonomi adalah potensi, inisiatif, dan daya kreasi setiap warga negara dikembangkan dalam batas-batas yang tidak merugikan kepentingan umum. Negara sangat mengakui setiap upaya dan usaha warga negaranya dalam membangun perekonomian.

Landasan pokok perekonomian Indonesia adalah Pasal 33 Ayat 1, 2, 3, dan 4 UUD 1945 hasil Amendemen, yang berbunyi sebagai berikut : Perekonomian disusun sebagai usaha bersama berdasarkan atas asas kekeluargaan. Cabang-cabang produksi yang penting bagi negara dan menguasai hajat hidup orang banyak dikuasai oleh negara. Bumi, air, dan kekayaan alam yang terkandung di dalamnya dikuasai oleh negara dan dipergunakan untuk sebesar besarnya kemakmuran rakyat.

Selain tercantum dalam penjelasan Pasal 33 UUD 1945, demokrasi ekonomi tercantum dalam Tap MPRS No. XXII/MPRS/1966 sebagai cita-cita sosial dengan ciri-cirinya. Selanjutnya, setiap Tap MPR tentang GBHN mencantumkan demokrasi ekonomi sebagai dasar pelaksanaan pembangunan dengan ciri-ciri positif yang selalu harus dipupuk dan dikembangkan. Ciri-ciri positif diuraikan dalam poin-poin berikut:

a. Perekonomian disusun sebagai usaha bersama berdasar atas asas ke keluargaan.

b. Cabang-cabang produksi yang penting bagi negara dan menguasai hajat hidup orang banyak dikuasai oleh negara.

c. Bumi, air, dan kekayaan alam yang terkandung di dalamnya dikuasai oleh negara dan dipergunakan untuk sebesar-besarnya kemakmuran rakyat.

d. Perekonomian nasional diselenggara kan berdasarkan atas demokrasi 
ekonomi dengan prinsip kebersamaan, efesiensi berkeadilan, berkelanjutan, berwawasan lingkungan, kemandirian, serta dengan menjaga keseimbangan kemajuan dan kesatuan ekonomi nasional.

e. Sumber-sumber kekayaan dan keuangan negara digunakan dengan pemufakatan lembaga-lembaga perwakilan rakyat.

f. Warga memiliki kebebasan dalam memilih pekerjaan dan penghidupan yanglayak. Hak milik perseorangan diakui pemanfaatannya tidak boleh bertentangan dengan kepentingan masyarakat.

g. Potensi, inisiatif, dan daya kreasi setiap warga negara dikembangkan dalam batas-batas yang tidak merugikan kepentingan umum.

h. Fakir miskin dan anak-anak terlantar dipelihara oleh negara.

Adapun ciri negatif yang harus dihindari dalam sistem perekonomian kita karena bersifat kontradiktif dengan nilainilai dan kepribadian bangsa Indonesia adalah sebagai berikut : Sistem Free Fight Liberalism, yang menumbuhkan eks ploitasi manusia dan bangsa lain. Sistem Etatisme, negara sangat dominan serta mematikanpotensi dan daya kreasi unit-unit ekonomi di luar sektor negara.

\section{Hukum Ekonomi Sebagai Panglima}

Politik hukum di Indonesia yang telah mengarahkan pembangunan hukum pada pertumbuhan ekonomi yang berkelanjutan, tampaknya sudah sangat mendesak untuk direalisir dengan program yang nyata oleh
Pemerintah. Namun yang patut mendapat perhatian, jangan sampai terjebak lagi dengan angka-angka pertumbuhan ekonomi tanpa memerhatikan pemerataan ekonomi bagi masyarakat miskin, sebagaimana yang dilakukan pada era Orde Baru.

Dimana Indonesia sempat terjebak dalam memposisikan hukum dalam konteks sebagai alat pembangunan semata, yang memang pada orde tersebut orientasi kebijakan ekonominya adalah pada perekonomian yang tinggi sebagai alat pemancing devisa negara yang ber cengkerama erat dengan tatanan politik, sehingga hukum menjadi terperangkap menjadi media untuk memberi justifikasi kebijakan negara tanpa koreksi, sehingga membuat terjebak dalam lingkaran kapitalisme semu yang menguntungkan pihak-pihak yang dekat dengan kekuasaan saja. Hukum ekonomi sebagai panglima, menurut buku ini menuntut mekanisme integral yang runtut, menjadi obor bagi kebijakan ekonomi sehingga mampu mendorong pertumbuhan ekonomi, serta merta menjadi pengayom dan memayungi isu pemerataan, pengentasan kemiskinan, dan pemilahan sektor ekonomi kerakyatan.

Dengan penggunaan strategi tersebut, diharapkan konglomerat-konglomerat yang telah 'dibesarkan' oleh penguasa akan 'meneteskan' rezekinya pada masyarakat miskin, sehingga terjadi pemerataan ekonomi.

Pada saat itu, program pembangunan Indonesia banyak mendapat pujian dari dunia internasional, diantaranya meraih swasembada beras, dan keberhasilannya memacu pertumbuhan ekonomi yang cukup tinggi sehingga menjadi salah satu 
Negara Asia yang mendapat julukan 'keajaiban Asia'.

Pembangunan hukum yang bersifat revolusioner, yaitu mengubah secara sadar dan mendasar system hukum ekonomi yang selama ini berkualitas 'liberal' dan dibawah kendali Negara-negara maju menjadi system hukum ekonomi yang berkualitas 'kekeluargaan (ukhuwah) atau kerakyatan, sebagaimana tertuang dalam nilai-nilai Pancasila dan Pasal 33 UUD 1945. System hukum ekonomi yang berkualitas 'kekeluargaan' atau 'kerakyatan', ini sebenarnya juga merupakan system hukum yang tidak sekedar mengandalkan pada rule of law tapi lebih menaruh perhatian pada rule of moral atau rule of justice. Sistem hukum tersebut kemudian diintegrasikan secara timbal balik dengan system ekonomi Pancasila.

Maka diperlukan sebuah penafsiran hukum yang mengarah pada penegakan hukum yang lebih menjunjung nilai moral dan nilai keadilan, tidak terpaku pada penegakan hukum yang kaku hanya pada undang-undang saja, tanpa memandang berani menafsirkan hukum demi terwujudnya keadilan. Indonesia sebagai Negara yang menganut positivism hukum, harus berani keluar dengan memberikan penafsiran-penafsiran yang luas demi terwujudnya keadilan.

Dengan pendekatan 'revolusioner' diharapkan pencapaian Visi Indonesia 2030 dilandasi dan dituntun oleh suatu sistem hukum ekonomi yang bersumber dari Pancasila dan Undang-Undang Dasar 1945 serta norma-norma yang hidup ditengah masyarakat (hukum adat dan hukum Islam).

Strategi pembangunan hukum ekonomi Indonesia perlu juga memerhati kan konsep pembangunan hukum ekonomi yang berkelanjutan (sustainable economic law development), yang melakukan pembangunan tidak lagi hanya sekedar melakukan 'bongkar pasang' pasal-pasal dalam suatu undang-undang atau pembuatan Undang-Undang baru saja, tetapi memerhatikan aspek yang lain. Aspek-aspek yang dimaksud disini mencakup berbagai dimensi yang luas, yang secara mendasar dapat disarikan menjadi tiga anasir sebagai berikut: (1) structur, (2) substance, dan (3) legal culture. Ketiga aspek ini diambil dari pendapat Lawrence M. Freidman, yang mana pendapat ini sering dirujuk dalam berbagai penelitian dan kajian sistem hukum di Indonesia. Dengan demikian, hukum dapat berkembang sesuai dengan pola perkembangan ekonomi dan hukum dapat menjawab semua permasalahan ekonomi yang ada.

Berkaitan dengan pengaruh sistem hukum dalam pembuatan produk perundang-undangan dibidang ekonomi, pada saat sekarang ini sistem hukum di Indonesia setidaknya sedang mengalami dua fenomena kolaboratif diametral yang acapkali tidak menunjukkan warna yang seirama. Fenomena pertama adalah disatu sisi 'tarikan dari atas dan kebawah terhadap sistem hukum Indonesia' oleh globalisasi hukum, dan di sisi adalah otonomi daerah. Kedua tarikan ini tentunya memberikan pengaruh terhadap bidang hukum ekonomi, baik dalam tataran konsep maupun implementasinya. Adapun fenomena kedua adalah 'terjadinya disharmonisasi akibat dualisme sistem hukum yang berlaku di Indonesia', yaitu antara sistem hukum Eropa Kontinental dan sistem hukum Anglo Saxon dan Common Law yang mewarnai hukum ekonomi terkini. 
Mikronasionalisme sistem hukum yang dimaksud adalah dimulainya orde hukum baru yang ditandai dengan bermunculannya peraturan-peraturan lokal beserta derivasinya sebagai akibat dibukanya keran otonomi daerah. Dewasa ini sudah diakui denga luas, betapa peraturab yang lebih rendah dari UndangUndang itu mampu membentuk 'orde hukum' tersendiri.

Guna menumbuhkan sinergi antara orde Undang-Undang dan orde peraturan lokal yang notabene merupakan bentuk tarikan kebawah terhadap sistem hukum Indonesia, diperlukan upaya-upaya pengawasan hukum. Namun ketika keterbatasan sistem pengawasan hukum formal yang dijalankan Mahkamah Agung muncul sebuah kendala, maka pengawasan hukum informal agaknya menjadi penting untuk dilakukan. Inilah tugas para akademisi, yaitu para doctor, professor dan cendikiawan diberbagai kampus di tanah air untuk menelurkan opinion doctorum. Sebuah upaya pengawasan informal yang juga dapat dilakukan secara sinergis dengan keterlibatan badan dan lembaga lain, seperti DPR, Lembaga Konsumen, Pers, Lembaga Bantuan Hukum dan sebagainya.

Adapun tarikan dari atas pada sistem hukum di Indonesia berupa pengaruh adanya globalisasi hukum terjadi melalui standarisasi hukum, antara lain, melalui perjanjian-perjanjian multilateral. Dalam hal ini hukum berusaha untuk melintasi atau membongkar hambatan ruang dan waktu, dengan menisbikan perbedaan sistem hukum. Globalisasi hukum merupakan gelombang kedua yang membawa kepentingan ekonomi global yang dikembangkan melalui prinsip liberalisasi perdagangan (trade liberalization) atau perdagangan bebas (free trade) lainnya.

Sebagimana dijelaskan, disepakatinya GATT-PU telah membawa konsekwensi Negara-negara anggota kehilangan kedaulatan untuk membuat perundang-undangan dalam bidang ekonomi, khususnya yang berkaitan dengan perdagangan, penanaman modal (investasi), jasa dan bidang hak kekayaan intelektual (HKI) dengan semua ketentuan yang ada pada GATT-PU. Kondisi ini jelas akan berpengaruh pada proses bekerjanya sistem hukum dalam masyarakat.

Perancang Undang-Undang, baik ditingkat pusat maupun daerah, harus mampu mengakomodasi 'tarikan kebawah dan ke atas' pada sistem hukum yang sekarang terjadi di Indonesia tersebut, yang kemudian secara cerdas diramu dengan isi Pasal 33 UUD 1945.

Selama ini banyak ketentuan peraturan perundang-undangan dibidang ekonomi hanya sekedar mencantumkan ketentuan Pasal 33 UUD 1945 dalam pertimbangan hukum dengan diselimuti kata 'mengingat', tanpa secara konsisten menindaklanjutinya dalam pasal-pasalnya, bahkan tidak jarang kita melihat ketentuan pasal-pasal dalam undang-undang tersebut tidak sinkron dan bahkan bertentangan dengan Pasal 33 UUD 1945, khususnya Ayat (1), (2) dan (3).

Pada era reformasi sebenarnya pemerintah bersama badan legislative telah banyak menghasilkan perundangundangan dibidang ekonomi. Namun demikian keberadaan peraturan perundangundangan yang dimaksudkan untuk mendukung bidang ekonomi ternyata 
belum mampu berperan optimal untuk menciptakan suasana kondusif bagi investor, meningkatkan kehadiran investasi asing, dan menopang perumbuhan ekonomi dalam rangka mengurangi angka penganguran, maupun menekan angka kemiskinan. Mencermati hal ini, pandangnan Satjipto Raharjo mengenai asas hukum patut mendapatkan perhatian.

Menurut Erman Rajagukguk, ketidakpastian hukum akan berpengaruh pada perekonomian. Ada 3 (tiga) factor yang menjadi penyebab tidak adanya kepastian hukum di Indonesia, yaitu pertama, hirarki peraturan perundangundangan tidak berfungsi dan masih tumpang tindihnya materi yang diatur, kedua, aparat lemah dalam menjalankan aturan, dan ketiga, penyelesaian sengketasengketa dibidang ekonomi tidak bisa diramalkan.

\section{Kesimpulan}

Pembangunan ekonomi haruslah dilakukan melalui landasan hukum yang kuat. Ekonomi merupakan tulang punggung kesejahteraan rakyat, dan ilmu pengetahuan adalah tiang-tiang penopang kemajuan bangsa, namun hukum merupakan pranata yang pada akhirnya menentukan bagaimana kesejahteraan rakyat tersebut dapat dinikmati secara merata, serta bagaimana keadilan sosial dapat diwujudkan dalam kehidupan masyarakat, dan bagaimana kemajuan ilmu pengetahuan dan teknologi dapat membawa kemajuan bagi rakyat banyak.

\section{Saran}

Kualitas pembangunan hukum ekonomi dipengaruhi oleh respon bidang hukum terhadap tuntutan bidang ekonomi, kemampuan mengharmonisasikan tekanan globalisasi hukum dan kepentingan rakyat dan tekanan system kapitalis di Indonesia oleh sebab itu pembangunan hukum ekonomi harus dilaksanakan secara revolusioner dengan menetapkan terlebih dahulu system ekonomi Indonesia yang berdasarkan Pasal 33 UUD 1945, sehingga mampu menghasilkan system hukum ekonomi yang tidak mengabdi pada negaranegara maju dan perusahaan-perusahaan trans nasional.

\section{DAFTAR PUSTAKA}

Aminuddin Ilmar, Konstruksi Teori dan Metode Kajian Ilmu Hukum. Makassar: Hasanuddin University Press, 2009.

Barda Nawawi Arief, Beberapa Pokok Pemikiran Kebijakan Penang gulangan Tindak Pidana Korupsi, Makalah yang disampaikan dalam seminar sehari tentang Mencari Solusi dan Model-model Pem berantasan Korupsi, Kolusi dan Manipulasi Di Lembaga Penegakan Hukum Indonesia, di Semarang pada tanggal 13 Agustus 1997.

Bryan A. Garner (ed.). 2004. Black's Law Dictionary. Seventh Edition. St. Paul Minesota: West Publishing

Fredmann. W, The State and The Rule of Law in Mix Economy, London teven \& Son 1971. 
Gunarto Suhardi, 2002, Peranan Hukum dalam Pembangunan Ekonomi, Universitas Atma Jaya Yogyakarta.

Hendricus Verland, Materi Training Finance criminal Investigation, kerjasama police academi of netherland dengan Polri, Ciputat, 19 Maret2012-5 April 2012.

J.E. Sahetapy (Ed.), Hukum Pidana, Yogyakarta: Liberty, 1996.
Martiman Prodjohamidjojo, Penerapan Pembuktian terbalik dalam Delik Korupsi (UU No. 31 tahun 1999), Bandung: Mandar Maju, 2001.

Mukthi Fadjar, M. Tipe Negara Hukum. Malang: Bayu Media dan InTRANS, 2004.

Rachmadi Usman, 2000. Hukum Ekonomi da lam Dinamika. Yang Menerbitkan Djambatan : Jakarta. 